\title{
Evaluation of Bambara Nut (Vigna subterranea) as Feed Ingredient in the Diet of the Catfish, Clarias gariepinus (Burchell 1822)
}

\author{
A. A. Adewumi , O. M. Odeyemi
}

\begin{abstract}
A 56-day (eight weeks) experimental trial was carried out in the laboratory to evaluate the effect of using Bambara nut, as protein source in the diet, on the growth performance and nutrient utilization of the catfish, Clarias gariepinus. The trial diets were formulated by replacing fishmeal with $0 \%, 20 \%, 30 \%, 40 \%$ and $50 \%$ Bambara groundnut meal (BGM) in diets tagged diets Q (control diet), A, B, C and D respectively. At the end of the study, The Mean weight gain (MWG), Daily weight gain (DWG), percentage weight gain (PWG of the fish fed diet D were significantly higher $(\mathrm{P}<0.05)$ than those of the other trial diets $\mathrm{A}, \mathrm{B}$ and $\mathrm{C}$ but not significantly higher $(\mathrm{P}<0.05)$ than those fed the control diet. The protein efficiency ratios (PER) were not significantly different $(\mathrm{P}=0.05)$ from one another. The apparent net protein utilization (ANPU) were significantly different $(\mathrm{P}<0.05)$ from one another, with diet A recording the least. The SGR of the various fish were not significantly different $(\mathrm{P}>0.05)$ from one another. However, the SGR of the fish fed diet D (0.89) was higher than those of the other trial diets, but lower than that of the control (0.91). The food conversion ratio of the fish fed diet $\mathrm{D}(7.49)$ was significantly lower $(\mathrm{P}>0.05)$ than those of the other diet, except the control diet. The findings showed that Bambara groundnut meal was accepted and digested by the experimental fish as the conventional fish meal. Conclusively, it can be inferred from this study that Bambara groundnut has the potential to be used as a protein source and can replace and elicit good growth in fish as the conventional fishmeal.
\end{abstract}

Keywords: Growth, Catfish, Legume, Alternative, Bambara

\section{INTRODUCTION}

Fish often comprises a nutritionally important part of many people's diets in developing countries. It is a vital source of protein and micronutrients, and improves the quality of protein in largely vegetable and starch-based diets by providing essential amino acids. (FAO, 2006) has estimated that fish accounts for approximately 20 percent of animal protein consumption in Low-Income Food-Deficit Countries (LIFDC).

Fish requires high quality nutritional balanced diet for growth and attainment of market size within the shortest possible time. Therefore, local production of fish-feed is very crucial to the development and sustainability of aquaculture in Africa and especially in rural areas. Fish feed technology is one of the least developed sectors of aquaculture, particularly in Africa and other developing countries of the world (FAO, 2003). Feed is one of the major inputs (40$60 \%$ in aquaculture production. It is one of the fundamental challenges facing the development and growth of aquaculture in the African continent.

Any complete diet must contain some protein, but the nutritional value of the protein relates directly to its amino acid composition and digestibility. Fishmeal is sought after as an ingredient in aquaculture diets because it contains special growth factor and compounds that make the feed more palatable and highly ingestible and digestible thus reducing nutrient leaching and wastages. However, the cost of fishmeal is now prohibitive, to poor resource farmers, hence this drive towards finding alternative protein sources. Sustainability remains a concern, however, even more so when the demand for aquaculture products is outstripping the supply, and prices soar. According to Hecht (2000), it is observed that the research on how best plant protein can be used as fish feed is the focus of fish nutritional research all over the world.

The bambara groundnut (Vigna subterranea) (Plate 1), also known by its common names; bambara bean, congo goober, earth pea, ground-bean, hog-peanut, congo groundnut, 'opa' etc, is a member of the family Fabaceae and sub family faboidea (Bamikole, 2005). The plants originate from West Africa (Nigeria, Cameroon, Central African Republic and Chad) and ripen its pods underground much like the peanut. They can be eaten fresh or boiled after drying. It is cultivated primarily for its seeds, which are used as human food. In Africa, it is the third most

This article is published under the terms of the Creative Commons Attribution License 4.0

Author(s) retain the copyright of this article. Publication rights with Alkhaer Publications.

Published at: http://www.ijsciences.com/pub/issue/2018-09/

DOI: 10.18483/ijSci.1784; Online ISSN: 2305-3925; Print ISSN: 2410-4477 
commonly eaten legume after peanut and cowpea (Omitoyin, 2006). The seeds are used in many types of foods, some of which are an important part of human diet. Mature, dry seeds are boiled and eaten as a pulse. The seeds can be milled to make flour.

According to Muir et al (2013), high carbohydrate $(65 \%)$ and relatively high protein $(18 \%)$ content as well as sufficient quantities of fat $(6.5 \%)$ makes the bambara groundnut a complete food. According to research by Igbinosun and Ajayi (1991) and validated by Bamikole (2005), bambara groundnut seeds have been found richer than peanuts (groundnut) in essential amino acids such as isoleucine, leucine, lysine, methionine, phenylanine, threonine and valine. The fatty acids content is predominantly linoleic, palmitic and linolenic acids (Kapetsky, 1994). Moly and Cech (1982) also reported that it contains relatively high proportions of lysine and methionine as percentage of the protein (6.6 and $1.3 \%$ respectively). The essential amino acid content of Bambara groundnut such as lysine $(6.82 \mathrm{~g} / 16 \mathrm{gN})$, methionine $(1.85 \mathrm{~g} / 16 \mathrm{gN})$ and cysteine $(1.24 \mathrm{~g} / 16 \mathrm{gN})$ is comparable to that of soybean methionine $(6.24 \mathrm{~g} / 16 \mathrm{gN})$ and cysteine $(1.80 \mathrm{~g} / 16 \mathrm{gN})$. Amarteifio et al., (2006) reported that Bambara groundnut is a good source of minerals and can be helpful in formulating a balanced diet.

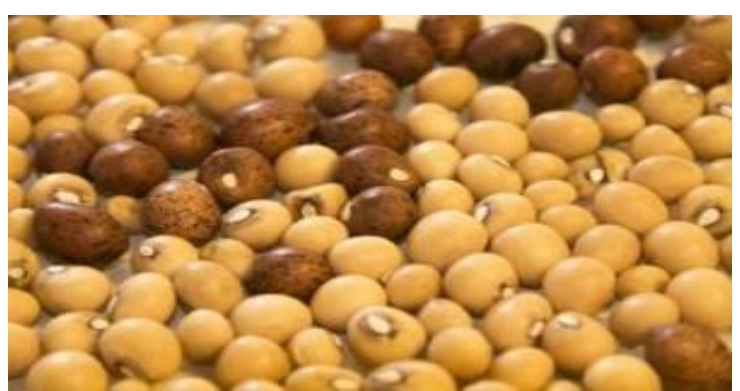

Plate 1: Bambara groundnut (Vigna subterranea)

In African countries such as Nigeria and Ghana, the seeds are pound and made into flour. The flour is usually added to maize to enrich traditional preparations and used to make a variety of cakes, or are mixed with cereals and used to prepare several types of porridge. In the early 1960s, bambara groundnut was canned in Ghana, in tomato sauce with pieces of meat, in brine, or as 'aboboi'. Bambara milk is processed in a similar way to that of soya bean, and is often used as weaning milk in many African countries. Several reports have concluded that bambara groundnut milk is rated higher in acceptability compared to other legume based milks such as soya bean and cowpea (Brummett, 2006). In Indonesia, Bambara groundnut is fried and eaten as a snack called 'kacangbogor'. Other uses of Bambara groundnut include use as animal feed. Seeds have been successfully used to feed chicks and the leaves are suitable for animal grazing because they are rich in nitrogen and phosphorus (Bamikole et al., 2011). In Nigeria, Jamu and Ayinla (2003) reported on the use of Bambara groundnut and leaf protein from Leucaena leucocephala or Gliricidia sepium in feeding tilapia fish. They reported that the fish grew quite well on this diet. The use of bambara groundnut meal as a fish meal substitute, to reduce the cost of fish feed, is receiving increasing attention by fish nutritionists around the world (Bairagi et al., 2004).

Bambara groundnut like most legumes, contain antinutritional factors like trypsin inhibitor, tannins, polyphenols, phytate and haemagglutinnin. Processing methods such as dehulling, milling, soaking, cooking, germination, fermentation, autoclaving, roasting and frying have been found to reduce/ eliminate theses anti-nutritional factors (FAO, 1990) which agrees with the result of this experiment. Soaking, drying and milling processes significantly reduced the trypsin inhibitor, tannins, phytate and haemagglutinninin of the BGN. The nutritional implication of these reductions in the concentration of trypsin inhibitor is that it will lead to improvement in protein digestibility. According to Bairagi et al., (2004) fermentation is a simple and cheap method to decrease the anti-nutritional factors and crude fibre contained in the plants by-products.

The goal of this research is to replace portions of fishmeal with Bambara groundnut meal (BGM), in the feeding of Clarias gariepinus, and monitor the effects of the feeding experiment on growth performance and nutrient utilization of the fish.

\section{MATERIALS AND METHODS \\ Experimental Site}

The experiment was carried out at the Animal House of the Department of Zoology and Environmental Biology, Ekiti State University, Ado-Ekiti.

\section{Procurement of Experimental Materials}

Two hundred pieces of Clarias gariepinus juveniles (av. Wt. 71.66 \pm 3.3g), were purchased from $\mathrm{Mr}$ Adebayo's hatchery in Ado-Ekiti, Ekiti state. The Bambara groundnut seeds were obtained from Oja Oba, Ikare Akoko, Ondo State. The other feed ingredients; Danish fish meal (72\% crude protein), maize, soya bean, salt, lysine, methionine, rice bran, vitamin/mineral premix, groundnut oil, were all purchased from MetroVet stores, Ado Ekiti.

\section{Experimental Design}

The fish samples were acclimatised and fed with Coppens commercial fish feed, at 3\% average body weight per day, for a period of two weeks. Prior to 

(Burchell 1822)

the commencement of the feeding trial, twenty pieces of the fish samples were randomly distributed into well labelled bowls in triplicates, for each treatment.

\section{Preparation of the Diets}

The Bambara groundnut seeds were soaked in water for twenty four hours and later sun dried and milled into fine powder, with a hammer mill. The meal was tagged BGM. Other feed ingredients used are maize, soya bean, rice bran, fish premix were also milled separately. Five dietary treatments consisting of various percentages $(0 \%, 20 \%, 30 \%, 40 \%$, and $50 \%)$ of fishmeal replacement with BGM were formulated and tagged diets Q, A, B, C, D The diet was prepared by weighing calculated amounts of each feed ingredients separately, using Pearson's square method (Wagner and Starton, 2017). The ingredients in each treatment were properly mixed together and pelleted to a particulate size, using a $2 \mathrm{~mm}$ pellet disc Hobart A120 pelleting machine (Hobart Manufacturing Ltd., London England). Mixing and pelleting was done at the feedmill of Afe Babalola University, Ado Ekiti (ABUAD). The pelleted feed was sundried and kept inside well labelled polythene bags, inside a deep freezer, till ready for use. The feed ingredients composition is as shown in Table 1.

\section{Biochemical Analysis}

The BGM, the diets and carcass proximate (crude protein, water, fat, ash and crude fibre) analysis were done at the Central Science Laboratory of Federal University of Technology Akure, Ondo State, according to the method of AOAC (2006). Table 2 and 3 show the proximate analysis of the BGM and the various experimental diets respectively.

Table 1: Formulation $\left(\mathrm{g} 100 \mathrm{~g}^{-1}\right.$ feed) of the various diets.

\begin{tabular}{llllll}
\hline Ingredients & Q & A & B & C & D \\
\hline BGM & - & 5.93 & 8.89 & 11.86 & 14.82 \\
Fish Meal & 29.64 & 23.71 & 20.75 & 17.78 & 14.82 \\
Maize & 33.18 & 33.18 & 33.18 & 33.18 & 33.18 \\
Rice Bran & 33.18 & 33.18 & 33.18 & 33.18 & 33.18 \\
Salt & 1 & 1 & 1 & 1 & 1 \\
Groundnut oil & 1 & 1 & 1 & 1 & 1 \\
Vitamin/Premix & 1 & 1 & 1 & 1 & 1 \\
Lysine & 0.5 & 0.5 & 0.5 & 0.5 & 0.5 \\
Methionine & 0.5 & 0.5 & 0.5 & 0.5 & 0.5 \\
& & & & & \\
\hline
\end{tabular}

Table 2: The proximate composition $\left(\mathrm{g} 100 \mathrm{~g}^{-1}\right)$ of the BGM.

\begin{tabular}{lllllr}
\hline Ash & Moisture & $\begin{array}{c}\text { Crude } \\
\text { Protein }\end{array}$ & Fat & Fibre & Carbohydrate \\
\hline 3.8 & 7.44 & 16.37 & 9.29 & 4.19 & 58.72 \\
\hline
\end{tabular}

Table 3: The proximate composition $\left(\% \mathrm{DM}^{-1}\right)$ of the experimental diets

\begin{tabular}{lllllll}
\hline \multicolumn{1}{l}{ PARAMETERS } & \multicolumn{2}{c}{ A } & B & C & D \\
\hline ASH & $10.13^{\mathrm{a}}$ & $13.02^{\mathrm{b}}$ & $12.60^{\mathrm{c}}$ & $13.18^{\mathrm{a}}$ & \multicolumn{2}{c}{$14.90^{\mathrm{a}}$} \\
MC & $7.13^{\mathrm{a}}$ & $6.29^{\mathrm{c}}$ & $7.04^{\mathrm{c}}$ & \multicolumn{2}{c}{$6.23^{\mathrm{b}}$} & \multicolumn{2}{c}{$6.54^{\mathrm{d}}$} \\
CP & $40.67^{\mathrm{c}}$ & $34.71^{\mathrm{b}}$ & $33.68^{\mathrm{c}}$ & $34.91^{\mathrm{a}}$ & $34.17^{\mathrm{c}}$ \\
FAT & $13.74^{\mathrm{a}}$ & $15.49^{\mathrm{c}}$ & $12.40^{\mathrm{b}}$ & $14.71^{\mathrm{a}}$ & $14.49^{\mathrm{a}}$ \\
FIBRE & $3.73^{\mathrm{b}}$ & $2.12^{\mathrm{a}}$ & $3.13^{\mathrm{b}}$ & $2.42^{\mathrm{c}}$ & $2.97^{\mathrm{b}}$ \\
CHO & $48.92^{\mathrm{a}}$ & $52.25^{\mathrm{b}}$ & $53.70^{\mathrm{a}}$ & $55.45^{\mathrm{c}}$ & $52.15^{\mathrm{d}}$ \\
\hline
\end{tabular}

a, b, c, d Different superscripts within the same row demonstrate significant differences $(\mathrm{p}>0.05)$. 


\section{Experimental Design, Feeding and Monitoring}

The labelled plastic aquarium tanks $(60 \mathrm{~cm} \times 30 \mathrm{~cm} \times 30 \mathrm{~cm})$ were filled with water up to two third volume and allocated in triplicates for each dietary treatment. These tanks were stocked at a density of 15 juvenile fish per tank. The fish were fed with the experimental diets at the rate of $3 \%$ of their body biomass per day, in two rations, between 9:0010:00am and 5:00-6:00pm, for 56days. The survival of the fish in the experimental tanks was monitored and recorded. Water in the bowl was replaced completely every other day and thorough cleaning of the tanks carried out bi-weekly.

\section{Growth Parameters}

The average initial weights $(\mathrm{gm})$ and lengths $(\mathrm{cm})$ of three samples of the fish used for the experiment were recorded. To determine the growth response of the fish, the weights were recorded every two weeks. From this, mean weight gain (MWG), Daily weight gain (DWG), Percentage weight gain (PWG), Daily feed intake, feed conversion ratio (FCR), specific growth rate (SGR), Protein efficiency ratio (PER), survival rate were calculated thus;

$\mathrm{FCR}=\underline{\text { Feed consumed }}$

Body weight gain

$\mathrm{SGR}=$

$\underline{\left(\log _{e} \text { final body weight }-\log _{\mathrm{e}} \text { initial body weight) }\right.} \times 100$ Days

Where $\mathrm{W}_{\mathrm{f}}=$ Final average weight at the end of the experiment.

$\mathrm{W}_{\mathrm{i}}=$ Initial average weight at the beginning of the experiment.

$\log _{\mathrm{e}}=$ Natural logarithm reading.
Survival rate

$$
\mathrm{S}=\frac{\mathrm{N}_{\mathrm{i}}}{\mathrm{N}_{0}} \times 100
$$

Where $S=$ Survival rate

$\mathrm{N}_{\mathrm{o}}=$ Total number of juvenile stocked at the beginning of the experiment

$\mathrm{N}_{\mathrm{i}}=$ Total number of juvenile alive at the end of the experiment.

MWG $=$ Mean final weight - mean initial weight

$\mathrm{PWG}=\underline{\mathrm{MWG}} \times 100$

Mean initial weight

Daily Feed Intake $=\underline{\text { Total feed intake }}$

Number of Days

Total feed intake $(\mathrm{TFI})=\underline{\text { Total weight of feed fed }}$

Number of Fish

\section{Water Quality Parameters}

The physico-chemical parameters of the water were monitored with LaMotte Fresh Water Aquaculture Test Kit, Model AQ-2, Code 3633-03, using the method of AOAC (2006).

\section{Statistical Analysis}

Statistical analysis of the growth performance and feed utilization parameters were carried out by one way analysis of variance (AVOVA), using the SPSS 15.0. The significant differences among mean were determined by the use of Duncan's Multiple Range Test (DMRT) (Duncan, 1995).

\section{RESULTS AND DISCUSSION}

Fig. 1 shows the growth performance of Clarias gariepinus fed the experimental diets. All the experimental diets lead to growth of the fish. The growth curve gave an indication of diet D performing better than other experimental diets, followed by diet C. The least performance was experienced in fish fed $\operatorname{diet} \mathrm{A}$. The growth performance of the fish fed diet D (50\% replacement) was comparable to that of the fish fed the control diet (Diet Q). 




Fig. 1: The growth performance of the fish fed the experimental diets.

After acclimatization, there was no mortality throughout the experimental period. Table 4 shows that there were significant differences $(\mathrm{P}<0.05)$ in the growth parameters evaluated. The Mean weight gain (MWG), Daily weight gain (DWG), percentage weight gain (PWG of the fish fed diet $\mathrm{D}$ were significantly higher $(\mathrm{P}<0.05)$ than those of the other trial diets $\mathrm{A}, \mathrm{B}$ and $\mathrm{C}$ but not significantly higher $(\mathrm{P}<0.05)$ than those fed the control diet. The protein efficiency ratios (PER) were not significantly different $(\mathrm{P}=0.05)$ from one another. The apparent net protein utilization (ANPU) were significantly different $(\mathrm{P}<0.05)$ from one another, with diet $\mathrm{A}$ recording the least. The SGR of the various fish were not significantly different $(\mathrm{P}>0.05)$ from one another. However, the SGR of the fish fed diet D (0.89) was higher than those of the other trial diets, but lower than that of the control (0.91). The food conversion ratio of the fish fed diet $\mathrm{D}$ (7.49) was significantly lower $(\mathrm{P}>0.05)$ than those of the other diet, except the control diet.

Table 4: Growth performance of Clarias gariepinus fed the various diets

\begin{tabular}{lccccc}
\hline PARAMETER & DIET Q & DIET A & DIET B & DIET C DIET D \\
\hline Mean initial weight & $70.28^{\mathrm{a}}$ & $72.06^{\mathrm{a}}$ & $72.14^{\mathrm{a}}$ & $71.80^{\mathrm{a}}$ & $72.00^{\mathrm{a}}$ \\
Mean final weight & $120.74^{\mathrm{a}}$ & $106.01^{\mathrm{b}}$ & $109.30^{\mathrm{ab}}$ & $108.84^{\mathrm{ab}}$ & $116.30^{\mathrm{a}}$ \\
Mean weight gain & $50.46^{\mathrm{a}}$ & $33.95^{\mathrm{a}}$ & $37.16^{\mathrm{ab}}$ & $37.04^{\mathrm{ab}}$ & $44.30^{\mathrm{a}}$ \\
Daily weight gain & $0.90^{\mathrm{a}}$ & $0.61^{\mathrm{b}}$ & $0.66^{\mathrm{b}}$ & $0.66^{\mathrm{b}}$ & $0.79^{\mathrm{ac}}$ \\
Percentage weight gain $71.80^{\mathrm{a}}$ & \multicolumn{1}{c}{$47.11^{\mathrm{b}}$} & $52.51^{\mathrm{b}}$ & $51.59^{\mathrm{b}}$ & $61.53^{\mathrm{a}}$ \\
Survival rate (\%) & $100^{\mathrm{a}}$ & $100^{\mathrm{a}}$ & $100^{\mathrm{a}}$ & $100^{\mathrm{a}}$ & $100^{\mathrm{a}}$ \\
Specific growth rate & $0.91^{\mathrm{a}}$ & $0.78^{\mathrm{a}}$ & $0.87^{\mathrm{a}}$ & $0.85^{\mathrm{a}}$ & $0.89^{\mathrm{a}}$ \\
PER & $0.82^{\mathrm{a}}$ & $0.89^{\mathrm{a}}$ & $0.82^{\mathrm{a}}$ & $0.81^{\mathrm{a}}$ & $0.83^{\mathrm{a}}$ \\
ANPU & $14.56^{\mathrm{a}}$ & $8.22^{\mathrm{b}}$ & $10.92^{\mathrm{c}}$ & $10.91^{\mathrm{c}}$ & $12.97^{\mathrm{d}}$ \\
FCR & $7.32^{\mathrm{a}}$ & $14.72^{\mathrm{b}}$ & $14.72^{\mathrm{b}}$ & $8.68^{\mathrm{c}}$ & $7.49^{\mathrm{d}}$ \\
\hline
\end{tabular}

a, b, c, d Different superscripts within the same row demonstrate significant differences $(p>0.05)$. 

(Burchell 1822)

The body composition also showed significant differences among diets (Table 5). Diet $\mathrm{D}$ gave a significantly higher $(\mathrm{P}<0.05)$ carcass body protein value $(68.22 \%)$ than the other diets, while Diet B had the lowest body protein $(54.81 \%)$. Diet $\mathrm{D}$ gave a high value for lipid $(8.88 \%)$, comparable to that of the control diet while the least was recorded for Diet C. The ash content of diets also indicated significant differences $(\mathrm{P}<0.05$. There were no significant differences $(\mathrm{P}>0.05)$ between Diets $\mathrm{Q}, \mathrm{A}$ and $\mathrm{D}$. The lowest ash content was recorded for diet C (4.31\%). There was significant decrease in the moisture content from the initial level of $33.35 \%$. Diet D ended up with the lowest value for moisture (14.21) which was significantly lower $(\mathrm{p}<0.05)$ than other diets.

Table 5: The proximate composition $\left(\% \mathrm{DM}^{-1}\right)$ of the fish fillets

\begin{tabular}{lcccccc}
\hline & Initial & Q & A & B & C & D \\
\hline Ash & $5.43^{\mathrm{a}}$ & $4.66^{\mathrm{a}}$ & $4.39^{\mathrm{b}}$ & $4.69^{\mathrm{a}}$ & $4.31^{\mathrm{b}}$ & $4.66^{\mathrm{a}}$ \\
Moisture & $33.35^{\mathrm{d}}$ & $15.48^{\mathrm{a}}$ & $19.68^{\mathrm{a}}$ & $22.78^{\mathrm{ab}}$ & $24.47^{\mathrm{b}}$ & $14.21^{\mathrm{c}}$ \\
C.P & $65.80^{\mathrm{d}}$ & $67.10^{\mathrm{a}}$ & $54.81^{\mathrm{a}}$ & $55.68^{\mathrm{a}}$ & $66.52^{\mathrm{b}}$ & $68.22^{\mathrm{ab}}$ \\
Fat & $7.26^{\mathrm{d}}$ & $8.91^{\mathrm{a}}$ & $8.03^{\mathrm{a}}$ & $8.43^{\mathrm{a}}$ & $6.30^{\mathrm{b}}$ & $8.88^{\mathrm{b}}$ \\
CHO & $2.22^{\mathrm{a}}$ & $0.17^{\mathrm{c}}$ & $0.19^{\mathrm{c}}$ & $2.32^{\mathrm{a}}$ & $3.34^{\mathrm{b}}$ & $3.19^{\mathrm{b}}$ \\
\hline
\end{tabular}

a, b, c, d Different superscripts within the same row demonstrate significant differences $(\mathrm{p}>0.05)$.

Table 6 shows the water quality parameters. That there was no fouling of the medium is an indication that the feedstuffs were good and acceptable to the fish. High percentage survival also justifies this and indicates no poisoning or and validates absence of toxins.

Table 6: Water quality parameters (av.) of the culture media before and after the feeding trials

\begin{tabular}{lccccc}
\hline Treatment & $\mathrm{pH}$ & $\begin{array}{l}\text { Conductivity } \\
(\mu \mathrm{s} / \mathrm{cm})\end{array}$ & Water Temp. $\left({ }^{0} \mathrm{C}\right)$ & $\begin{array}{l}\text { Dissolved } \\
\left(\mathrm{mg} \mathrm{l}^{-1}\right)\end{array}$ \\
\hline Initial & 6.8 & 76.2 & 26.5 & 7.1 \\
Q & 7.1 & 78.3 & 26.0 & 6.8 \\
$\mathrm{~A}$ & 7.4 & 81.2 & 26.9 & 7.6 \\
$\mathrm{~B}$ & 7.1 & 82.2 & 26.4 & 7.3 \\
$\mathrm{C}$ & 7.2 & 74.7 & 27.3 & 6.9 \\
$\mathrm{D}$ & 7.5 & 78.3 & 26.0 & 6.8 \\
\hline
\end{tabular}

In the present study, fish fed the experimental diets showed increase in weight without any sign of nutritional deficiency. Fish fed Bambara groundnut meal (BGM) diets, at various level up to $50 \%$ replacement recorded appreciable weight gain, percentage weight gain and specific growth rate, comparable to the control diet. This observation is in agreement with Oso et al. (2013) who reported that replacement of fishmeal with BGM up to a level of $75 \%$ was satisfactorily acceptable to the fish just like the fish meal and could replace fish meal protein in the diet of Clarias gariepinus, without adversely affecting growth and feed utilization. Enyidi and Mgbenka (2015) also reported that Bambara nut waste meal can supplement up to $59 \%$ of fishmeal in the diets of the larvae of $C$. gariepinus. This shows that Bambara groundnut (BGN) contains necessary growth factors required by Clarias gariepinus. The fish showed good appetite to all the treatment diets as attested to by the increase in body weight. The observation shows that the juveniles were able to utilize bambara nut diet efficiently like conventional fish meal. This might also be due to good digestibility of the diet. In agreement with previous authors (Muir et al. 2013; Oso et al., 2013; Enyidi and Mgbenga, 2015), this study has revealed that Bambara groundnut is a good protein source that can be utilized in supplementing the diet of Clarias gariepinus.

\section{CONCLUSION}

This study has demonstrated that Bambara groundnut meal can be used to replace fishmeal protein to a level of up to $50 \%$, in the diet of Clarias gariepinus, without adversely affecting growth and feed utilization. Bambara groundnut seed has been shown to make a balanced food as it contains sufficient quantities of nutrients (carbohydrate, protein and fats) necessary for fish growth and therefore recommended for use as a fishmeal replacer in fish culture.

\section{REFERENCES}

1. Amarteifio J. O.; Tibe O. and Njogu R. M. (2006). The mineral composition of Bambara groundnut, Vigna 
subterranea (L) (Verdc) grown in Southern Africa. African J. of Biotech. 5(23): 2408-2411.

2. AOAC (Association of Official Analytical Chemists) (2006) Official methods of Analysis. $17^{\text {th }}$ Edition. Williams S. (Ed.). Arlington, V.A. 1125p.

3. Bairagi, A.K.; Sarkar-Ghash, S.; Sen, K. and Ray, A.K. (2004). Evaluation of the nutritive value of Bambara groundnut meal, inoculated with fish intestinal bacteria Bascillus subtilis and Bascillus circulans in formulated diets for rohu, Labeo rohita (Hamilton) fingerlings. Aquac. Res. 35: 436-446.

4. Bamikole, M.A.; Ikhatuam, M.I.; Ikhatua, U.J. and Evenwa, I.V. (2005). Nutritive value of bambara nut in the growing of rabbit in Nigeria . Pakistan J. Nutr. 4:231-236.

5. Brummett, W.A.; Malekano, L.B. and Ambali, A.J. D. (2006). Potential of Genetics for Aquaculture Development in Africa. NAGA 26:31-35.

6. Duncan, D.B. (1995). Multiple range and multiple F-test. Biometrics, 11:1-22.

7. FAO (1990). Fisheries and Aquaculture in Sub Sahara Africa: situation and outlook in 1990. FAO Fisheries Circular No. 992. p 16.

8. FAO, (2003) Fisheries Statistics http://fao.org.Accessed 13 ${ }^{\text {th }}$ Jan 2006.

9. FAO, (2006). Potential of Genetics for Aquaculture Development in Africa, p. 47.

10. Hecht, T. (2000). Consideration on African Aquaculture. World Aquac. 31:12-19.

11. Jamu, D.M. and Ayinla, O.A. (2003). Potentials for the Development of Aquaculture in Africa. NAGA.26 : 6-13.

12. Kapetsky, J.M. (1994). A strategic assessment of warm water fish farming potential in Africa. IFA Technical paper No 27. FAO, Rome. p 67.

13. Muir, J.F.; Gitonga, N.; Omar, I.; Poumorpre, V. And Radwan, I. (2005). Hidden harvest unlocking the potential of aquaculture in Africa. NEPAD Fish for all Summit, 22-25 May Abuja Nigeria. p.56.

14. Enyidi, U. D. and Mgbenka B. O. (2015). Replacement of fish meal with Bambara nut waste meal in the diets of larval African catfish, Clarias gariepinus (Burchell 1822). British J. of Applied Sci. and Tech. 5(6): 526-537.

15. Moly, P.B. and Cech, J.J. (1982). Fishes: An introduction to Ichthyology, Prentice-Hall, Inc., New Jersey, p.25-32.

16. Omitoyin, B. O. (2006). Fish hatchery management. An invited Technical paper presented at a two-days Fisheries seminar on "Post Retirement Sustainability: Prospects of Investment in Fisheries, organized by the Ministry of Agriculture and National Resources and Rural Development, Fisheries Department, Agodi Ibadan, p 18-19.

17. Oso, J.A.; Edward, J.B.; Ogunleye, O.A. and Majolagbe, F.A. (2013): Growth response and feed utilization of Clarias gariepinus fingerlings fed with Bambara groundnut as protein source. J. of Natural Sci. Res. 3(5): 84-90 